Note: This is a pre-copy-editing, author-produced PDF of an article accepted for publication in Addiction following peer review. The definitive publisher-authenticated version [ter Bogt $\mathrm{T}$, Schmid $\mathrm{H}$. Nic Gabhainn S, Fotiou A, and Vollebergh W (2006), Economic and cultural correlates of cannabis use among mid-adolescents in 31 countries, Addiction, 2006, 101, 241-251] is available online at http://www.informaworld.com/smpp/title content=t713655978

\title{
Economic and cultural correlates of cannabis use among mid-adolescents in 31 countries
}

\author{
Tom ter Bogt 1,, Holger Schmid 2, Saoirse Nic Gabhainn 3 , Anastasios Fotiou 4 \& Wilma \\ Vollebergh 1 \\ 1 Trimbos Institute, Utrecht, the Netherlands \\ 2 Swiss Institute for the Prevention of Alcohol and Drug Problems, Lausanne, Switzerland \\ 3 Department of Health Promotion, National University of Ireland, Galway, Ireland \\ 4 University Mental Health Research Institute, Athens, Greece
}

Published in Addiction, 2006, 101, , 241-251

Copyright: Wiley-Blackwell

\section{Correspondence to:}

Tom ter Bogt, Trimbos-instituut, PO Box 725, 3500 AS Utrecht, The Netherlands, E-mail: tbogt@trimbos.nl

\begin{abstract}
Aims: To examine cannabis use among mid-adolescents in 31 countries and associations with per-capita personal consumer expenditure (PCE), unemployment, peer factors and national rates of cannabis use in 1999.
\end{abstract}

Design, participants and measurement: Nationally representative, self-report, classroom survey with 22223 male and 24900 female 15-year-olds. Country characteristics were derived from publicly available economic databases and previously conducted cross-national surveys on substance use. Findings: Cannabis use appears to be normative among mid-adolescents in North America and several countries in Europe. The life-time prevalence of cannabis use was $26 \%$ among males and $15 \%$ among females and was lowest for males and females in the former Yugoslav Republic (TFYR) of Macedonia: $2.5 \%$ and to $2.5 \%$, respectively; and highest for males in Switzerland (49.1\%) and in Greenland for females (47.0\%). The highest prevalence of frequent cannabis use (more than 40 times in life-time) was seen in Canada for males (14.2\%) and in the United States for females (5.5\%). Overall, life-time prevalence and frequent use are associated with PCE, perceived availability of cannabis (peer culture) and the presence of communities of older cannabis users (drug climate).

Conclusions: As PCE increases, cannabis use may be expected to increase and gender differences decease. Cross-national comparable policy measures should be developed and evaluated to examine which harm reduction strategies are most effective.

Keywords: Adolescents, cannabis, international comparisons, personal consumer expenditure.

\section{INTRODUCTION}

In many countries in Europe and North America cannabis is a widely used substance among adolescents, as reflected in life-time and current prevalence estimates [1-5]. During the 1990s there was a general increase in cannabis consumption among adolescents, but recent estimates suggest major fluctuations. The 2004 US Monitoring the Future Report concluded that during the last 3 years cannabis use among American students has decreased [6]. In Europe, life-time and last month prevalences still vary widely across countries that participate in the European School Survey Project on Alcohol and Other Drugs (ESPAD) and the Health Behaviour in School-aged Children (HBSC) studies. The life-time prevalence of cannabis use among the ESPAD and HBSC target group of mid-adolescent 15-year-old students has, in some countries, increased to over $40 \%$, while in others it is well below $10 \%$ [3,5]. While 
there is a broad literature on personality, parental, peer and policy factors associated with the illicit substance use, investigations into cross-national differences in cannabis use are relatively rare $[7,8]$. In contrast, cross-national surveys of alcohol consumption are more prevalent (e.g. [9]) and countrylevel characteristics such as gross domestic product [10] and unemployment [11] have been shown to covary with both alcohol use and misuse.

Cannabis use first became a mass phenomenon in industrialized countries in the 1960s among white, middle-class youth and has been described as existing within a social environment generally favouring procannabis attitudes and behaviour, in which cannabis was (perceived to be) easily available $[12,13]$. These aspects of drug culture in a particular country are associated with frequent use of cannabis $[3,14]$. Cannabis use has also been shown to be associated with socio-economic status [15]. Thus, cannabis use may be more prevalent in economically prosperous countries that have relatively large groups of young people with both disposable income and increased leisure opportunities, willing to pass on their drugusing behaviour to younger peers. Alternatively, cannabis use may be more prevalent among marginal groups who use the drug as a means of coping with personal difficulties [16-19]. It is possible, however, that marginalized youth in less affluent countries may simply be too poor to purchase cannabis and in some rich countries it may simply be hard to obtain.

Mid-adolescence (15-16 years) is a critical period for initiation to cannabis [20] and initiation in this period or earlier is an indicator of possible drug misuse and related problems later in life (e.g. [21,22]). Adolescents' peers have a strong influences on perceptions of drug availability, substance use attitudes and behaviour during this time [23-26]. In part, this influence operates because young people who have friends who use use substances are more likely to think that drug use is normative and thus appropriate [27-30].

Research on the explanation of cross-national differences in cannabis use is scarce. In this paper we first examine the differences in cannabis use in 31 countries in Europe and North America. Secondly, using hierarchical generalized linear model analysis, the variation in patterns of use between countries is analysed by (1) national characteristics, including the socio-economic indicators of wealth and youth unemployment, (2) indicators of drug climate, i.e. the countries past agglomerated scores on life-time and last month cannabis use and (3) indicators of peer drug culture, i.e. acquaintance with and perceived availability of cannabis, and perception of friends' cannabis use. With this project we extend previous research on correlates of cannabis use, but while most previous attempts to make international comparisons have relied on secondary analysis of surveys with different question structures that have been administered in non-equivalent ways, the advantage of the current work is that the same survey was administered in the same way in all countries, using the same sampling strategy.

\section{METHOD}

\section{Sample}

The 2001/2002 Health Behaviour in School-Aged Children Study is a World Health Organization (WHO)-supported study of nationally representative samples of adolescents in 36 countries and regions [31]. In each country, a cluster sample design is employed with school classes as sampling units. Schools and classes within schools were selected to be representative by age level and regional geography. The recommended sample sizes for each country were 1536 students per age group. Sample sizes assured a 95\% confidence interval of approximately $3 \%$ for prevalence estimates, and took the clustering effect of school classrooms into account [32]. It was not possible to correct for the clustering effect of classrooms in the statistical analysis because unique identifiers for individual classrooms were not supplied by all participating countries. The present analysis is based on 22223 male and 24900 female students aged 15 years from 31 countries, who answered on the cannabis questions. The multilevel analysis included only 31 of the 36 countries participating in HBSC because of missing socioeconomic indicators or missing data on cannabis use, acquaintance, availability or beliefs about the drug use of friends. The 31 countries included were Austria, Belgium, Canada, Croatia, Czech Republic, Denmark, Estonia, Finland, France, Germany, Greenland, Hungary, Ireland, Israel, Italy, Greece, 
Latvia, Lithuania, Malta, the Netherlands, Poland, Portugal, Russia, Slovenia, Spain, Sweden, Switzerland, Ukraine, the Former Yugoslav Republic of Macedonia (herein, Macedonia), United Kingdom (not including Northern Ireland) and United States.

\section{Measures}

Data were collected at two levels. At the individual level, data include students' self-reported cannabis use. Second-level data comprise information on private consumer expenditure (PCE; an indicator of personal spending power) and youth employment from the United Nations Economic Commission for Europe economic database [33], and cross-national means on lifetime and last month prevalences, acquaintance, availability and belief about friends drug use from the 1999 ESPAD and MTF studies [3,4]. As a control, rates of missing data by country were also included.

Descriptions of the cannabis questionnaire items employed and their development have been reported elsewhere [32,34-35]. National questionnaires are translations and adaptations of the international standard version, with independent re-translation back to English, to maximize comparability. The present report utilizes the following questionnaire secondary data set measures.

\section{Cannabis use}

In addition to self-reported life-time prevalence of cannabis use, respondents were asked to recall the frequency of cannabis use in the past year, using the following categories: 'never', 'once or twice', 'three to five times', 'six to nine times', '10-19 times', '20-39 times' and 'more than 39 times'. Those who reported using cannabis 40 times and more last year were categorized as 'frequent users' and this binary indicator was used for statistical modelling.

\section{Drug climate}

The cannabis use of communities of older adolescents in the participating countries and was taken as an indicator of local drug climate. Their drug use is reported in recent survey on substance use. Country means of (1) life-time and (2) last month prevalence of cannabis use in 1999 were taken from the 1999 ESPAD and Monitoring the Future studies [3,4].

\section{Peer culture}

In order to assess perceptions of peer drug culture we employed (1) cannabis acquaintance (percentage of respondents indicating that they have heard of marijuana or hashish), (2) perceived availability (percentage of respondents indicating availability is 'fairly easy' or 'very easy') and (3) belief about friends use (percentage of respondents indicating that some, most or all of their friends use marijuana or hashish) from the ESPAD and MTF 1999 surveys [3,4].

\section{Socio-economic indicators}

Country characteristics were taken from the UN/ECE economic database [33]. This database contains crossnational indicators of (1) per capita private consumer expenditure (PCE 2001) in American dollars and (2) the percentage of youth unemployment (PCE 2001).

\section{Statistical analysis}

A hierarchical generalized linear model (HGLM [36-38]) was employed. HGLM has been used for the analysis of longitudinal data [39] and is a recommended procedure for analysis of crosssectional epidemiology data sets [40]. The data were structured hierarchically with variables at 
both the individual and the country levels. To account for this structure a multi-level regression model which assumes hierarchical data was applied [41], with one criterion measured at the lowest level and predictors at all existing levels. In this study the criterion variables were lifetime cannabis use and frequent cannabis use (both binary), and tested through a binary outcome model that uses a binomial sampling model. The predictors were national characteristics measured at the country level. Level one units were the adolescents and level two units the countries. The software used was HLM version 5.04 [30,42]. This program is able to analyse a sequence of several models.

We tested four consecutive models. First, a socioeconomic model with PCE, youthemployment and the interaction between PCE and youth unemployment as predictors; secondly, a peer culture model with the acquaintance, availability and peer drug use variables; thirdly, a drug climate model with cross-national indicators of past, i.e. 1999, life-time and last month prevalance. Finally, we intended to test a complete model with all the significant predictors from the three preceding analyses.

\section{RESULTS}

\section{Descriptive results}

A total of 50816 students in 31 countries, 24137 males (47.5\%) and 26679 females (52.5\%), completed questionnaires and $47123(92.7 \%)$ answered all questions about cannabis use.

Table 1 gives a description of the individual level data by country. The mean life-time prevalence of cannabis use was $25.8 \%$ for males and $14.5 \%$ for females. The percentage of students having tried cannabis at least once varies from $3.8 \%$ in Macedonia to $49.1 \%$ in Switzerland for males, and from $2.5 \%$ in Macedonia to $47.0 \%$ in Greenland for females. AngloAmerican countries (Canada, United Kingdom, United States) and Switzerland and Greenland have relatively high prevalences of life-time cannabis use, whereas most countries from eastern and northern Europe, except Czech Republic, Hungary, Slovenia and Ukraine, have a low prevalence.

Mediterranean countries, except Spain and to a lesser extent Italy and Portugal (Malta, Israel, Greece and Macedonia) also tend to have relatively low prevalence estimates. Most western European countries rank in between (Belgium, Denmark, France, Germany, Ireland, the Netherlands) On the whole, boys have higher prevalence rates than girls, gender differences generally being greatest in the countries from eastern and southern Europe (Table 1). 
Table 1 Description of individual level data for 15-year-olds from the 2002 Health Behaviour in School-aged Children study (HBSC).

\begin{tabular}{|c|c|c|c|c|c|c|c|c|}
\hline \multirow[b]{2}{*}{ Country } & \multicolumn{4}{|c|}{ Boys } & \multicolumn{4}{|c|}{ Girls } \\
\hline & Valid n & $\begin{array}{l}\text { Missing } \\
\text { data }(\%)\end{array}$ & $\begin{array}{r}\text { Life-time } \\
\text { cannabis } \\
\text { use }(\%)\end{array}$ & $\begin{array}{r}\text { Frequent } \\
\text { cannabis } \\
\text { use }(\%)\end{array}$ & Valid $n$ & $\begin{array}{l}\text { Missing } \\
\text { data }(\%)\end{array}$ & $\begin{array}{r}\text { Life-time } \\
\text { cannabis } \\
\text { use }(\%)\end{array}$ & $\begin{array}{l}\text { Frequent } \\
\text { cannabis } \\
\text { use }(\%)\end{array}$ \\
\hline Austria & 596 & 9.6 & 14.7 & 1.2 & 592 & 7.4 & 12.7 & 1.0 \\
\hline Belgium & 1603 & 3.3 & 28.5 & 5.8 & 1706 & 2.7 & 22.5 & 2.2 \\
\hline Canada & 476 & 9.8 & 47.9 & 14.2 & 640 & 5.7 & 41.6 & 4.4 \\
\hline Croatia & 600 & 4.2 & 18.9 & 2.7 & 804 & 2.0 & 14.1 & 0.6 \\
\hline Czech Rep & 781 & 3.1 & 34.6 & 3.3 & 844 & 1.2 & 26.7 & 2.4 \\
\hline Denmark & 646 & 2.7 & 25.8 & 2.6 & 699 & 2.4 & 21.1 & 0.3 \\
\hline Estonia & 614 & 0.8 & 23.0 & 0.7 & 645 & 0.5 & 11.6 & 0.0 \\
\hline Finland & 827 & 4.9 & 11.0 & 1.0 & 845 & 3.4 & 9.6 & 0.2 \\
\hline France & 1254 & 3.6 & 34.1 & 6.0 & 1269 & 3.4 & 26.0 & 3.1 \\
\hline Germany & 800 & 5.3 & 27.8 & 5.1 & 858 & 5.1 & 20.2 & 1.3 \\
\hline Greenland & 82 & 18.8 & 44.2 & 3.6 & 122 & 12.2 & 47.0 & 2.5 \\
\hline Hungary & 506 & 1.2 & 16.5 & 2.2 & 812 & 0.7 & 10.8 & 0.2 \\
\hline Ireland & 326 & 5.5 & 27.4 & 6.1 & 552 & 3.8 & 15.2 & 2.3 \\
\hline Israel & 640 & 9.6 & 8.3 & 1.7 & 798 & 7.1 & 4.2 & 0.6 \\
\hline Italy & 545 & 0.5 & 26.9 & 3.7 & 677 & 0.6 & 17.6 & 3.0 \\
\hline Greece & 619 & 3.7 & 8.0 & 1.3 & 674 & 1.0 & 2.7 & 0.1 \\
\hline Latvia & 440 & 9.3 & 16.1 & 0.9 & 592 & 6.3 & 8.8 & 0.0 \\
\hline Lithuania & 973 & 0.9 & 11.2 & 0.5 & 920 & 0.3 & 4.5 & 0.0 \\
\hline Malta & 275 & 12.1 & 9.2 & 1.1 & 320 & 9.6 & 3.9 & 0.0 \\
\hline Netherlands & 621 & 2.5 & 28.5 & 4.3 & 629 & 1.1 & 23.3 & 1.3 \\
\hline Poland & 1019 & 1.7 & 25.0 & 2.6 & 1109 & 0.5 & 11.6 & 0.3 \\
\hline Portugal & 356 & 6.1 & 25.5 & 4.2 & 387 & 8.5 & 14.6 & 1.8 \\
\hline Russia & 1065 & 6.4 & 19.0 & 0.6 & 1345 & 6.4 & 9.3 & 9.3 \\
\hline Slovenia & 536 & 3.8 & 31.0 & 5.8 & 505 & 1.4 & 25.4 & 2.6 \\
\hline Spain & 785 & 4.4 & 36.1 & 7.2 & 879 & 6.0 & 33.1 & 3.6 \\
\hline Sweden & 599 & 2.4 & 7.6 & 0.7 & 600 & 2.0 & 6.6 & 0.5 \\
\hline Switzerland & 735 & 7.0 & 49.1 & 13.8 & 699 & 6.8 & 40.1 & 5.0 \\
\hline Ukraine & 711 & 2.6 & 33.2 & 0.6 & 858 & 1.5 & 15.2 & 0.0 \\
\hline $\begin{array}{l}\text { TFYR of } \\
\text { Macedonia }\end{array}$ & 660 & 2.9 & 3.8 & 0.0 & 716 & 2.2 & 2.5 & 0.1 \\
\hline United Kingdom & 1866 & 6.1 & 39.5 & 7.7 & 2001 & 4.7 & 35.9 & 3.8 \\
\hline USA & 667 & 11.5 & 41.6 & 11.4 & 803 & 7.8 & 30.5 & 5.5 \\
\hline Total & 22223 & 7.9 & 25.8 & 4.2 & 24900 & 6.7 & 14.5 & 1.3 \\
\hline
\end{tabular}

The highest prevalence of frequent use of cannabis is observed in Canada for males $(14.2 \%)$ and in the United States for females (5.5\%), while no use of cannabis more than 40 times in the last year is reported in Macedonia for males and in Estonia, Latvia, Lithuania, Malta and Ukraine for females. The geographical patterning of frequent use is similar to that of life-time prevalence. Anglo-American countries (Canada, United Kingdom, United States) have relatively high instances of frequent use with rates within the same range in Switzerland and Spain. Prevalences are relatively low in most northern, eastern and Mediterranean countries. In between these extremities settles a group of countries with moderate prevalences, consisting mainly of countries of western Europe (Belgium, France, Germany, Greenland, Italy, Portugal and Slovenia). Frequent cannabis use is more common among boys than girls (Table 1) (see also Ter Bogt, Fotiou \& Nic Gabhainn [43]). 
Missing data on the questions about cannabis use are rare in Italy for males $(0.5 \%)$ and in Lithuania for females $(0.3 \%)$, but are substantial in Greenland for both genders $(18.8 \%$ males; $12.2 \%$ females). Table 2 shows a description of characteristics found for the different participating countries, derived from the UN/ECE economic database and the ESPAD study [3]. National per capita PCE, an indicator of economic prosperity, is lowest for Macedonia $(\mathrm{PCE}=3.7)$ and highest for the United States $(\mathrm{PCE}=24.4)$. Youth unemployment rates also differ considerably between countries, with Switzerland ranking lowest (5.6\%) and Macedonia highest $(56.1 \%)$. The data from the ESPAD Study show high proportions of respondents indicating having heard of marijuana or hashish, with rates varying from $76 \%$ in Greenland to $98 \%$ in Italy. The proportions of respondents indicating the availability of cannabis as being 'fairly easy' or 'very easy' is lowest in Malta and Ukraine (11\%) and highest in the United States (78\%). The percentage of respondents indicating that some, most or all of their friends use marijuana or hashish is low in Hungary (2\%) and high in the United States (45\%).

\section{Results of multi-level modelling}

The results of the HGLM were calculated for male and female students separately. The individual level criteria are life-time cannabis use and frequent cannabis use. Different models were calculated for different country level predictors and the complete multilevel model includes all predictors simultaneously. Table 3 shows the estimated coefficients, standard errors, degrees of freedom and significance levels by model and gender.

The probability that a male student will use cannabis at least once in his life is estimated as between 0.212 and 0.243 depending on the calculated model. The intercept is the expected logodds of cannabis use for a student with mean values on the predictors. The expected log-odds corresponds to a probability of $1 /\left[1+\exp \left(-\gamma_{00}\right)\right]$, which is the population average for this group. The probability estimates for frequent use vary between 0.022 and 0.038 depending on the model. For female students, the probability of life-time cannabis use is estimated between 0.136 and 0.178 and the probability of frequent use between 0.007 and 0.016 .

According to the economic model, the odds of using cannabis at least once in a life-time and of using cannabis frequently are higher in countries with high PCE, for both genders. Neither youth unemployment nor the interaction between PCE and youth unemployment accounted for any of the variance in cannabis use. Within the peer culture model, for both genders perceived availability was associated significantly with both life-time and in frequent use. In countries where availability is perceived as easy, the odds of using cannabis are higher. However, in this model acquaintance with cannabis and friends use did not predict cannabis use. Within the drug climate model both the 1999 ESPAD/MTF rates of life-time and 30-day prevalences were associated with current cannabis use. Analysis of the missing data indicated that these did not have any predictive value for either the lifetime or frequent use of cannabis. In the complete model, which included the significant predictors identified from the first three models, the 1999 ESPAD/MTF rates of both life-time and last month prevalences were significant predictors of current cannabis use. The other correlates of cannabis use from the economic and peer culturemodels, PCE and perceived availability did not reach statistical significance. This indicates that the existing drug climate (operationalized as the presence of groups of cannabis using young people in a country) is the strongest predictor of current cannabis use. It should be noted, however, that in this last model only 21 countries remain in the analysis. Finally, the analysis of the factors associated with cannabis use shows that, even though females are less likely to use 
cannabis than males, the relationships between the second level predictors and reported individual use similar for both genders.

Table 2 Description of level two data for country characteristics.

\begin{tabular}{|c|c|c|c|c|c|}
\hline Country & $\begin{array}{r}\text { UN/ECE private } \\
\text { per capita consumer } \\
\text { expenditure(PCE/1000, } \\
\text { in dollars) }\end{array}$ & $\begin{array}{r}\text { UN/ECE youth } \\
\text { unemployment } \\
\text { rate }\end{array}$ & $\begin{array}{r}\text { ESPAD } \\
\text { acquaintance:\% } \\
\text { heard of cannabis }\end{array}$ & $\begin{array}{r}\text { ESPAD } \\
\text { availability: \% } \\
\text { very easy or } \\
\text { fairly easy }\end{array}$ & $\begin{array}{r}\text { ESPAD friends: } \\
\text { belief about \% some, } \\
\text { most or all of my } \\
\text { friends use cannabis }\end{array}$ \\
\hline Austria & 16.3 & & & & \\
\hline Belgium & 15.1 & 15.3 & & & \\
\hline Canada & 16.7 & 12.8 & & & \\
\hline Croatia & 5.0 & 37.3 & 93.0 & 29.0 & 19.0 \\
\hline Czech Rep & 8.0 & 16.6 & 98.0 & 50.0 & 11.0 \\
\hline Denmark & 14.0 & 8.3 & 96.0 & 57.0 & 23.0 \\
\hline Estonia & 5.7 & 22.2 & 93.0 & 19.0 & 12.0 \\
\hline Finland & 13.3 & 19.9 & 91.0 & 20.0 & \\
\hline France & 14.7 & 18.7 & 95.0 & 44.0 & 34.0 \\
\hline Germany & 15.7 & 8.4 & & & \\
\hline Greenland & & & 76.0 & 13.0 & 11.0 \\
\hline Hungary & 6.7 & 10.8 & 95.0 & 19.0 & 2.0 \\
\hline Ireland & 14.1 & 6.2 & 92.0 & 59.0 & 24.0 \\
\hline Israel & 10.5 & 18.5 & & & \\
\hline Italy & 15.9 & 27.0 & 98.0 & 43.0 & 44.0 \\
\hline Greece & 11.5 & 28.0 & 94.0 & 33.0 & 10.0 \\
\hline Latvia & 4.8 & 20.7 & 93.0 & 18.0 & 12.0 \\
\hline Lithuania & 5.4 & 30.2 & 86.0 & 15.0 & 7.0 \\
\hline Malta & 5.9 & 15.4 & 96.0 & 11.0 & 3.0 \\
\hline Netherlands & 14.6 & 5.8 & 87.0 & 41.0 & 17.0 \\
\hline Poland & 6.4 & 41.0 & 86.0 & 30.0 & 8.0 \\
\hline Portugal & 11.0 & 9.2 & 87.0 & 26.0 & 16.0 \\
\hline Russia & 4.3 & 18.0 & 95.0 & 22.0 & 4.0 \\
\hline Slovenia & 9.5 & 16.1 & 96.0 & 47.0 & 26.0 \\
\hline Spain & 12.6 & 20.8 & & & \\
\hline Sweden & 12.8 & 11.8 & 97.0 & 26.0 & 6.0 \\
\hline Switzerland & 18.3 & 5.6 & & & \\
\hline Ukraine & 2.4 & & 78.0 & 11.0 & 12.0 \\
\hline $\begin{array}{l}\text { TFYR of } \\
\text { Macedonia }\end{array}$ & 3.7 & 56.1 & & & \\
\hline United Kingdom & 17.2 & 10.5 & 96.0 & 52.0 & 34.0 \\
\hline USA & 24.4 & 10.6 & & 78.0 & 45.0 \\
\hline
\end{tabular}


Table 3 Results for the hierarchical generalized linear model (HGLM): estimated coefficients, standard errors, degrees of freedom and significance levels by model and gender.

\begin{tabular}{|c|c|c|c|c|c|c|c|c|}
\hline Model & $\begin{array}{l}\text { Country level } \\
\text { predictor }\end{array}$ & $\begin{array}{l}\text { Individual level } \\
\text { criterion }\end{array}$ & Parameter & Coefficient & SE & $\mathrm{df}$ & $\mathrm{P}$ & $\begin{array}{r}1 /(1+\exp \{- \\
\gamma 00\})\end{array}$ \\
\hline \multicolumn{9}{|l|}{ Males } \\
\hline \multirow[t]{4}{*}{ Economic } & Intercept & $\begin{array}{l}\text { Life-time cannabis } \\
\text { use }\end{array}$ & $\gamma_{00}$ & -1.205 & 0.128 & 24 & 0.000 & 0.231 \\
\hline & $\begin{array}{l}\text { Private consumer } \\
\text { expenditure }\end{array}$ & & $\gamma_{01}$ & 0.067 & 0.033 & 24 & 0.052 & \\
\hline & $\begin{array}{l}\text { Youth unemployment } \\
\text { rate }\end{array}$ & & $\gamma_{02}$ & -0.014 & 0.018 & 24 & 0.432 & \\
\hline & $\begin{array}{l}\text { PCE x Youth } \\
\text { unemployment }\end{array}$ & & $\gamma_{03}$ & 0.004 & 0.166 & 24 & 0.982 & \\
\hline \multirow[t]{4}{*}{ Economic } & Intercept & $\begin{array}{l}\text { Frequent cannabis } \\
\text { use }\end{array}$ & $\gamma_{00}$ & -3.417 & 0.142 & 24 & 0.000 & 0.032 \\
\hline & $\begin{array}{l}\text { Private consumer } \\
\text { expenditure }\end{array}$ & & $\gamma_{01}$ & 0.137 & 0.036 & 24 & 0.001 & \\
\hline & $\begin{array}{l}\text { Youth unemployment } \\
\text { rate }\end{array}$ & & $\gamma_{02}$ & -0.012 & 0.019 & 24 & 0.553 & \\
\hline & $\begin{array}{l}\text { PCE x youth } \\
\text { unemployment }\end{array}$ & & $\gamma_{03}$ & 0.030 & 0.186 & 24 & 0.873 & \\
\hline \multirow[t]{4}{*}{ Peer Culture } & Intercept & $\begin{array}{l}\text { Life-time cannabis } \\
\text { use }\end{array}$ & $\gamma_{00}$ & -0.310 & 0.104 & 15 & 0.000 & 0.212 \\
\hline & Acquaintance & & $\gamma_{01}$ & -0.028 & 0.028 & 15 & 0.336 & \\
\hline & Availability & & $\gamma_{02}$ & 0.023 & 0.010 & 15 & 0.040 & \\
\hline & $\begin{array}{l}\text { Belief about friends } \\
\text { use }\end{array}$ & & $\gamma_{03}$ & 0.015 & 0.013 & 15 & 0.249 & \\
\hline \multirow[t]{4}{*}{ Peer Culture } & Intercept & $\begin{array}{l}\text { Frequent cannabis } \\
\text { use }\end{array}$ & $\gamma_{00}$ & -3.735 & 0.116 & 15 & 0.000 & 0.023 \\
\hline & Acquaintance & & $\gamma_{01}$ & -0049 & 0.031 & 15 & 0.136 & \\
\hline & Availability & & $\gamma_{02}$ & 0.034 & 0.011 & 15 & 0.007 & \\
\hline & $\begin{array}{l}\text { Belief about friends } \\
\text { use }\end{array}$ & & $\gamma_{03}$ & 0.028 & 0.013 & 15 & 0.051 & \\
\hline \multirow[t]{2}{*}{ Drug Climate } & Intercept & $\begin{array}{l}\text { Life-time cannabis } \\
\text { use }\end{array}$ & $\gamma_{00}$ & -0.310 & 0.095 & 22 & 0.000 & 0.213 \\
\hline & $\begin{array}{l}\text { Life-time prevalence } \\
\text { in } 1999\end{array}$ & & $\gamma_{01}$ & 0.054 & 0.009 & 22 & 0.000 & \\
\hline \multirow[t]{2}{*}{ Drug Climate } & Intercept & $\begin{array}{l}\text { Frequent cannabis } \\
\text { use }\end{array}$ & $\gamma_{00}$ & -3.780 & 0.122 & 22 & 0.000 & 0.022 \\
\hline & $\begin{array}{l}30 \text { days prevalence in } \\
1999\end{array}$ & & $\gamma_{01}$ & 0.136 & 0.020 & 22 & 0.000 & \\
\hline \multirow[t]{2}{*}{ Missing data } & Intercept & $\begin{array}{l}\text { Life-time cannabis } \\
\text { use }\end{array}$ & $\gamma_{00}$ & -0.136 & 0.145 & 29 & 0.000 & 0.243 \\
\hline & Missing data & & $\gamma_{01}$ & 0.033 & 0.037 & 29 & 0.383 & \\
\hline \multirow[t]{2}{*}{ Missing data } & Intercept & $\begin{array}{l}\text { Frequent cannabis } \\
\text { use }\end{array}$ & $\gamma_{00}$ & -3.233 & 0.193 & 29 & 0.000 & 0.038 \\
\hline & Missing data & & $\gamma_{01}$ & 0.072 & 0.049 & 29 & 0.154 & \\
\hline \multirow[t]{4}{*}{$\begin{array}{l}\text { Complete } \\
\text { model }\end{array}$} & Intercept & $\begin{array}{l}\text { Life-time cannabis } \\
\text { use }\end{array}$ & $\gamma_{00}$ & -1.242 & 0.086 & 17 & 0.000 & 0.224 \\
\hline & $\begin{array}{l}\text { Private consumer } \\
\text { expenditure }\end{array}$ & & $\gamma_{01}$ & -0.021 & 0.030 & 17 & 0.508 & \\
\hline & Availability & & $\gamma_{02}$ & 0.004 & 0.013 & 17 & 0.779 & \\
\hline & $\begin{array}{l}\text { Life-time prevalence } \\
\text { in } 1999\end{array}$ & & $\gamma_{03}$ & 0.049 & 0.015 & 17 & 0.004 & \\
\hline \multirow[t]{4}{*}{$\begin{array}{l}\text { Complete } \\
\text { model }\end{array}$} & Intercept & $\begin{array}{l}\text { Frequent cannabis } \\
\text { use }\end{array}$ & $\gamma_{00}$ & -3.705 & 0.107 & 17 & 0.000 & 0.024 \\
\hline & $\begin{array}{l}\text { Private consumer } \\
\text { expenditure }\end{array}$ & & $\gamma_{01}$ & 0.026 & 0.035 & 17 & 0.477 & \\
\hline & Availability & & $\gamma_{02}$ & 0.019 & 0.013 & 17 & 0.161 & \\
\hline & Life-time prevalence & & $\gamma_{03}$ & 0.063 & 0.028 & 17 & 0.037 & \\
\hline
\end{tabular}


in 1999

Females

\begin{tabular}{|c|c|c|c|c|c|c|c|c|}
\hline \multirow[t]{4}{*}{ Economic } & Intercept & $\begin{array}{l}\text { Life-time cannabis } \\
\text { use }\end{array}$ & $\gamma_{00}$ & -0.656 & 0.139 & 24 & 0.000 & 0.160 \\
\hline & $\begin{array}{l}\text { Private consumer } \\
\text { expenditure }\end{array}$ & & $\gamma_{01}$ & 0.087 & 0.036 & 24 & 0.023 & \\
\hline & $\begin{array}{l}\text { Youth unemployment } \\
\text { rate }\end{array}$ & & $\gamma_{02}$ & -0.017 & 0.019 & 24 & 0.401 & \\
\hline & $\begin{array}{l}\text { PCE x Youth } \\
\text { unemployment }\end{array}$ & & $\gamma_{03}$ & -0.010 & 0.181 & 24 & 0.957 & \\
\hline \multirow[t]{4}{*}{ Economic } & Intercept & $\begin{array}{l}\text { Frequent cannabis } \\
\text { use }\end{array}$ & $\gamma_{00}$ & -4.467 & 0.186 & 24 & 0.000 & 0.011 \\
\hline & $\begin{array}{l}\text { Private consumer } \\
\text { expenditure }\end{array}$ & & $\gamma_{01}$ & 0.180 & 0.047 & 24 & 0.001 & \\
\hline & $\begin{array}{l}\text { Youth unemployment } \\
\text { rate }\end{array}$ & & $\gamma_{02}$ & -0.003 & 0.025 & 24 & 0.904 & \\
\hline & $\begin{array}{l}\text { PCE x youth } \\
\text { unemployment }\end{array}$ & & $\gamma_{03}$ & 0.138 & 0.243 & 24 & 0.575 & \\
\hline \multirow[t]{4}{*}{ Peer Culture } & Intercept & $\begin{array}{l}\text { Life-time cannabis } \\
\text { use }\end{array}$ & $\gamma_{00}$ & -1.846 & 0.127 & 15 & 0.000 & 0.136 \\
\hline & Acquaintance & & $\gamma_{01}$ & -0.007 & 0.034 & 15 & 0.833 & \\
\hline & Availability & & $\gamma_{02}$ & 0.030 & 0.012 & 15 & 0.026 & \\
\hline & $\begin{array}{l}\text { Belief about friends } \\
\text { use }\end{array}$ & & $\gamma_{03}$ & 0.018 & 0.015 & 15 & 0.275 & \\
\hline \multirow[t]{4}{*}{ Peer Culture } & Intercept & $\begin{array}{l}\text { Frequent cannabis } \\
\text { use }\end{array}$ & $\gamma_{00}$ & -4.916 & 0.221 & 15 & 0.000 & 0.007 \\
\hline & Acquaintance & & $\gamma_{01}$ & -0.012 & 0.061 & 15 & 0.851 & \\
\hline & Availability & & $\gamma_{02}$ & 0.051 & 0.021 & 15 & 0.027 & \\
\hline & $\begin{array}{l}\text { Belief about friends } \\
\text { use }\end{array}$ & & $\gamma_{03}$ & 0.043 & 0.025 & 15 & 0.110 & \\
\hline \multirow[t]{2}{*}{ Drug Climate } & Intercept & $\begin{array}{l}\text { Life-time cannabis } \\
\text { use }\end{array}$ & $\gamma_{00}$ & -1.798 & 0.115 & 22 & 0.000 & 0.142 \\
\hline & $\begin{array}{l}\text { Life-time prevalence } \\
\text { in } 1999\end{array}$ & & $\gamma_{01}$ & 0.065 & 0.011 & 22 & 0.000 & \\
\hline \multirow[t]{2}{*}{ Drug Climate } & Intercept & $\begin{array}{l}\text { Frequent cannabis } \\
\text { use }\end{array}$ & $\gamma_{00}$ & -4.969 & 0.173 & 22 & 0.000 & 0.007 \\
\hline & $\begin{array}{l}30 \text { days prevalence in } \\
1999\end{array}$ & & $\gamma_{01}$ & 0.192 & 0.028 & 22 & 0.000 & \\
\hline \multirow[t]{2}{*}{ Missing data } & Intercept & $\begin{array}{l}\text { Life-time cannabis } \\
\text { use }\end{array}$ & $\gamma_{00}$ & -1.530 & 0.166 & 29 & 0.000 & 0.178 \\
\hline & Missing data & & $\gamma_{01}$ & 0.085 & 0.054 & 29 & 0.126 & \\
\hline \multirow[t]{2}{*}{ Missing data } & Intercept & $\begin{array}{l}\text { Frequent cannabis } \\
\text { use }\end{array}$ & $\gamma_{00}$ & -4.113 & 0.240 & 29 & 0.000 & 0.016 \\
\hline & Missing data & & $\gamma_{01}$ & 0.126 & 0.078 & 29 & 0.118 & \\
\hline \multirow[t]{4}{*}{$\begin{array}{l}\text { Complete } \\
\text { model }\end{array}$} & Intercept & $\begin{array}{l}\text { Life-time cannabis } \\
\text { use }\end{array}$ & $\gamma_{00}$ & -1.805 & 0.102 & 17 & 0.000 & 0.141 \\
\hline & $\begin{array}{l}\text { Private consumer } \\
\text { expenditure }\end{array}$ & & $\gamma_{01}$ & -0.007 & 0.036 & 17 & 0.860 & \\
\hline & Availability & & $\gamma_{02}$ & 0.008 & 0.015 & 17 & 0.595 & \\
\hline & $\begin{array}{l}\text { Life-time prevalence } \\
\text { in } 1999\end{array}$ & & $\gamma_{03}$ & 0.050 & 0.018 & 17 & 0.012 & \\
\hline \multirow[t]{4}{*}{$\begin{array}{l}\text { Complete } \\
\text { model }\end{array}$} & Intercept & $\begin{array}{l}\text { Frequent cannabis } \\
\text { use }\end{array}$ & $\gamma_{00}$ & -4.942 & 0.193 & 17 & 0.000 & 0.007 \\
\hline & $\begin{array}{l}\text { Private consumer } \\
\text { expenditure }\end{array}$ & & $\gamma_{01}$ & 0.061 & 0.063 & 17 & 0.346 & \\
\hline & Availability & & $\gamma_{02}$ & 0.014 & 0.023 & 17 & 0.544 & \\
\hline & $\begin{array}{l}\text { Life-time prevalence } \\
\text { in } 1999\end{array}$ & & $\gamma_{03}$ & 0.121 & 0.050 & 17 & 0.028 & \\
\hline
\end{tabular}




\section{DISCUSSION}

Occasional cannabis use has become normative among a substantial minority of adolescents especially in Anglo-American countries, Switzerland, Greenland and Spain. A substantial minority of North American and European high school-age students have tried or use cannabis. Anglo-American countries (Canada, United Kingdom, United States) and Switzerland and Greenland have a relatively high prevalence of life-time cannabis use, whereas most countries from eastern and northern Europe, and most Mediterranean countries have relatively low prevalence figures. Countries from western Europe fall between these extremes. The patterning of frequent cannabis use is similar. Anglo-American countries, Switzerland and Spain have relatively high instances of frequent use. Prevalences are relatively low in most northern, eastern and Mediterranean countries, and most countries from western Europe hold an intermediate position.

The relative amount of missing data on the cannabis use item differs greatly between the countries. Our analysis cannot separate the possible reasons for missing data, such as forgetting to answer, poor comprehension of the question and fear appraisal because of the illicit character of the behavior. However, no systematic relationship between the amount of missing data and lifetime prevalence and frequent use of cannabis was found.The absence of a relationship could reflect that nonresponders do not differ from responders in terms of drug use behaviour, a finding that has already been reported elsewhere [44].

We sought to model the associations between macroeconomic indicators-PCE, youth unemployment — and manifestations of existing drug culture and cannabis use among 15-yearolds. Our results illustrate that in wealthy countries young people use cannabis more frequently. This may stem from increased leisure opportunities for larger segments of the population in wealthier countries. These opportunities include cannabis use and young people may be the first and most frequent users of the drug. Within Europe large differences in social wealth still exist between countries. Across Europe we may expect an increase in cannabis use, particularly in the central and eastern European regions where cannabis use is currently relatively infrequent, and marketorientated economies are developing rapidly.

Another important phenomenon concerns growing economic wealth and gender. Throughout Europe and North America, boys tend to report higher cannabis prevalence and more frequent drug use. The differences between boys and girls are generally smaller in the wealthier countries in this sample. Patterns of drug use in Anglo-American and western countries may be indicative of potential changes in these patterns in Southern, Central and Eastern European countries, as increasing wealth appears to be associated with a higher prevalence of cannabis use among females. Accordingly, gender differences, expressed traditionally as females' using cannabis less often than males, may also decrease in the near future.

Although we did not find an association between cannabis use and youth unemployment we cannot conclude that unemployed young people do not use more cannabis. An overall socioeconomic measure such as youth unemployment may, by definition, be too general to assess the potential link between individual marginality and drug use. Individual unemployment, or deprivation conceptualized as perceived social marginality, associated as such with personal psychological characteristics and weak interpersonal ties, may influence drug use but these factors were not within the remit of this study. Previously measured cannabis use was 
conceptualized as a proxy measure of an objectified 'drug climate': the existence of a group of users from which younger people can learn where to obtain cannabis and how to use it.

We found evidence that this aspect of drug culture is related to the behaviour of the younger members of the population. Older users may pass on their knowledge and habits to the willing and interested among their younger peers. Next, 'peer culture' is an important facilitator of cannabis use: the perception young people have of their social environment is associated with their own drug use. young people living in countries where knowledge of the existence of the drug is disseminated throughout youth culture, where they think that many of their peers use drugs and where availability (through friends) is perceived as easy, are more likely to use cannabis.

The generalized perception of an existing peer drug culture within a country is associated both with experimentation and frequent use of the drug. Within 'peer culture', perceived availability stands out as the single most important predictor.

Thus, our results show that countries' wealth (PCE) the existence of drug-using older youngsters ('drug climate') and young people's generalized perception that cannabis is readily available ('peer culture') are associated with cannabis use. 'Drug climate' appeared to be the strongest predictor of cannabis use among 15-year-olds, both for girls and boys, and it is the only remaining significant predictor left in the full model. As both PCE and availability are correlated with 'drug climate', this set of relationships may indicate mediation [45], i.e. 'drug climate' mediates the relationship between wealth and availability on one side and cannabis use on the other.

Historically, the sequence may be that wealth and availability foster the emergence of a drugusing community of young people but once this community exists, it plays a crucial role in the socialization of younger, potential cannabis users. We speculate that leisure opportunities for a rising middle class may facilitate drug use among the most bohemian segments of its youth, and that these behaviours trickle down to (some) young people with a lower social economic status once they have the money and opportunity to buy drugs. Future research should explore this process of mediation in more detail, both theoretically and historically.

However, our data also show that wealth is by no means a sufficient cause for cannabis use. Within the group of countries with high PCE large differences exist in use of the drug. For example, the Anglo-American countries all have high life-time prevalences and relatively large groups of frequent users while some Scandinavian countries, for example Sweden, report extremely low proportions of both experimenters and frequent users. Policy may make a difference. While we were able to incorporate macro-economic indicators, it was impossible to model other possible factors influencing drug use. To our knowledge, there exists no crossnationally comparable policy indicators, and therefore our study is limited in this context. Along with uncovering the mechanisms through which macro-economic indicators work, crossnational research should be directed at operationalizing comparable policy indicators and identifying those policies that prevent groups of young people from becoming frequent users, or that are successful in breaking the link between drug climate and use.

Large-scale cross-national research on the determinants of cannabis use is scarce. The strength of this study is that the same survey was carried out in each country with the same questionnaire and sampling strategy. This is rare, as most studies of this kind are based on secondary analyses of national surveys with different conceptual frameworks. The data 
presented here make it possible to explore cross-nationally some of the factors that are associated with cannabis use. Nevertheless, we acknowledge study limitations. First, the HBSC survey was conducted in classroom settings. The advantage of this is that response rates in classrooms are high, but children who drop out of school or play truant are less likely to be included in school surveys. Because these are both known risk factors for cannabis use their exclusion could bias school survey results, leading to lower cannabis prevalence estimates. Secondly, the cross-sectional study design allowed us to report on associations of country level variables for cannabis use, without any assessment of causality. It would be valuable to try to combine largescale surveys with a longitudinal design to study causal mechanisms in greater detail. Thirdly, only aggregated data on country levels were used in our models to predict cannabis use. These models would have been more sophisticated if predictors at the individual level had been added, i.e. in addition to aggregated data on PCE, unemployment drug climate and peer-use measures of individual spending power, job status, contacts in the drug scene and cannabis use by friends. These data would have enabled a more precise picture to be drawn of the link between macrofactors and microfactors and their interaction, and drug use. Our results provide evidence for the value of cross-national comparison of the antecedents of cannabis use. The challenge for future cross-national studies is to include aggregated and non-aggregated predictors in a longitudinal design to provide a better understanding of the social, economic and personal determinants of cannabis use.

\section{Acknowledgements}

HBSC is a WHO/EURO collaborative study. International Coordinator of the 2001/02 study: Candace Currie, University of Edinburgh, Scotland; Data Bank Manager: Oddrun Samdal, University of Bergen. This publication on the 2001/02 survey reports on data from the following countries (principal investigator(s) at that time): Austria

(Wolfgang Dür), Belgium (Flanders: Lea Maes; French: Danielle Piette), Canada (Will Boyce), Croatia (Marina Kuzman), Czech Republic (Ladislav Csémy), Denmark

(Pernille Due, Bjørn E. Holstein), Estonia (Mai Maser), Finland (Jorma Tynjälä), France

(Emmanuelle Godeau), Germany (Klaus Hurrelmann), Greenland (Michael Pedersen), Hungary (Anna Aszmann), Ireland (Saoirse Nic Gabhainn), Israel (Yossi Harel), Italy (Franco Cavallo), Greece (Anna Kokkevi), Latvia (Iveta Pudule), Lithuania (Apolinaras Zaborskis), Malta (Marianne Massa), Netherlands (Wilma Vollebergh), Poland (Barbara Woynarowska), Portugal (Margarida Gaspar de Matos),

Russia (Alexander Komkov), Slovenia (Eva Stergar), Spain (Carmen Moreno Rodriguez), Sweden (Ulla Marklund), Switzerland (Holger Schmid), Ukraine (Olga Balakireva), TFYR of Macedonia (Lina Kostarova Unkovska), United Kingdom [regions: England (Antony Morgan), Scotland (Candace Currie), Wales (Chris Roberts)] and United States (Mary Overpeck).

\section{References}

1. Costa e Silva JA. Evidence based analysis of the word wide abuse of licit and illicit drugs. Hum Psychopharmacol 2002;17: 131-40.

2. European Monitoring Centre for Drugs and Drug Addiction (EMCDDA). The state of the drugs problem in the European Union and Norway. Lisbon: EMCDDA; 2003.

3. Hibell B, Andersson B, Ahlström S, Balakireva O, Bjarnasson T, Kokkevi A, et al. The 1999 ESPAD Report: alcohol and other drug use among students in 30 European countries. Stockholm: Swedish Council for Information on Alcohol and Other Drugs (CAN)/The Pompidou Group at the Council of Europe; 2000. 
4. Johnston L, Bachmann G, O'Malley P. Monitoring the Future. National Survey Results an Adolescent Drug Use: Overview of Key Findings, 1999. Bethesda, MD: National Institute on Drug Abuse; 2000.

5. Nic Gabhainn S, François Y. Substance use. In: Currie C, Hurrelmann K, Settertobulte W, Smith R, Todd J, editors. Health and health behaviour among young people. Copenhagen:

World Health Organization, Regional Office for Europe; 2000, pp. 97-114.

6. Johnston LD, O'Malley PM, Bachman JG, Schulenberg JE. Monitoring the future: national results on adolescent drug use: overview of key findings, 2004. Bethesda, MD: National Institute on Drug Abuse; 2005.

7. Brook JS, Brook DW, Arenchibia-Mireles O, Richter L, Whiteman M. Risk factors for adolescent marijuana use across cultures and across time. J Genet Psychol 2001;162: 357-74.

8. Zoccolillo M, Price R Jr, Tedd JI, Hwu HG. Antisocial personality disorder: comparisons of prevalence, symptoms, and correlates in four countries. In: Cohen P,

Slomkowski C, Robbins LN, editors. Historical and geographical influences on psychopathology. Mahwah, NJ: Erlbaum, 1999, pp. 249-78.

9. Schmid H, Nic Gabhainn S. Alcohol use. In: Currie C, Roberts C, Morgan A, Smith R, Settertobulte W, Samdal O et al., editors. Young people's health in context: health behaviour in school-aged children (HBSC) study: international report from the 2001/2002 survey.

Copenhagen: World Health Organization, Regional Office for Europe; 2004, pp. 73-83.

10. Castro FG, Gutierres S. Drug and alcohol use among rural Mexican-Americans. In:

Robertson EB, Sloboda Z, Boyd GM, Beatty L, Kozel NJ, editors. Rural substance abuse: state of knowledge and issues. NIH Publication no. 97-4177. Rockville, MD: National Institute on Drug Abuse; 1997, pp. 498-533.

11. Claussen B. Alcohol disorders and re-employment in a 5-year follow-up of long-term unemployed. Addiction 1999;94: 133-8.

12. Miller T. The hippies and American values. Knoxville: University of Tennessee Press; 1991.

13. ter Bogt T. De geschiedenis van jeugdcultuur en popmuziek [On the history of youth culture and pop]. In: ter Bogt T, Hibbel B, eds., Wilde Jaren [Wild Years]. Utrecht: Lemma; 2000, pp. 24-130.

14. Carvajal SC, Photiades JR, Evans RI, Nash SG. Relating a social influence model to the role of acculturation in substance use among latino adolescents. J Appl Soc Psychol 1997;27:

1617-28.

15. Hall W, Degenhardt L, Lynskey M. The health and psychological effects of cannabis use.

Monograph series no. 25. Canberra: National Drug and Alcohol Research Centre University of New South Wales; 2001.

16. Bartley M, Ferrie J, Montgomery SM. Living in a high unemployment economy. In: Marmot M, Wilkinson RG, editors. Understanding the health consequences: social determinants of Health. Oxford: Oxford University Press; 1999, pp. 81-104.

17. Channabasavanna SM, Mehdi P, Hall W. Mental and behavioral disorders due to cannabis use. In: Kalant H, Corrigall W, Hall W, Smart RG, editors. The health effects of cannabis. Toronto: Centre for Addiction and Mental Health, Addiction Research Foundation; 1999, pp. 267-90.

18. Shaw M, Dorling D, Davey Smith G. Poverty, social exclusion, and minorities. In: Marmot M, Wilkinson RG, editors. Social determinants of health. Oxford: Oxford University Press; 1999, pp. 211-39.

19. Yamaguchi K, Kandel DB. Patterns of drug use from adolescence to young adulthood III. Predictors of progression. Am J Public Health 1984;74: 673-81. 
20. Lintonen T, Rimpela M, Vikat A, Rimpela A. The effect of societal changes on drunkenness trends in early adolescence. Health Educ Res 2000;15: 261-9.

21. Brook J, Balka E, Whiteman M. The risks for late adolescence of early marijuana use. Am J Public Health 1999;89: 1549-54.

22. Brook JS, Adams RE, Balka E, Johnson E. Early adolescent marijuana use: risks for the transition to young adulthood. Psychol Med 2002;32: 79-91.

23. Akers RL, Krohn MD, Lanze-Kaduce L, Radosevich M. Social learning and deviant behavior: a specific test of a general theory. Am Sociol Rev 1979;44: 636-55.

24. Jessor R, Jessor SL. Problem behavior and psychological development: a longitudinal study of youth. New York: Academic Press; 1977.

25. Kaplan HB, Martin SS, Robins C. Application of a general theory of deviant behavior: selfderogation and adolescent drug use. J Health Soc Behav 1982;2: 274-94.

26. Petraitis J, Flay BR, Miller TQ, Torpy EJ, Greiner B. Illicit substance use among adolescents: a matrix of prospective predictors. Subst Use Misuse 2000;33:2561-604.

27. Bauman KE, Ennett ST. On the importance of peer influence for adolescent drug use: commonly neglected considerations. Addiction 1996;91: 185-98.

28. Hansen WB. All stars. Sixth/seventh grade curriculum, version1.60s. Tanglewood: Research Inc.; 1998.

29. Hansen WB, O’Malley PM. Drug use. In: DiClemente RJ, Hansen WB, Ponton L E, eds. Handbook of adolescent healthrisk behaviour. New York: Plenum Press; 1996, pp. 161-92. 30. Schmid H. Cannabis use in Switzerland: the role of attribution of drug use to friends, urbanization and repression. Swiss J Psychol 2001;60: 99-107.

31. Currie C, Roberts C, Morgan A, et al., editors. Young people's health in context: health behaviour in school-aged children (HBSC) study: international report from the 2001/2002 survey. Copenhagen: World Health Organization, Regional Office for Europe; 2004.

32. Currie C. Health behaviour in school-aged children: research protocol for the 1997-98 survey. Copenhagen: World Health Organization Coordinating Centre for the Study of Health Behaviour in School-aged Children; 1998.

33. United Nations Economic Commission for Europe. Trends in Europe and North-America. New York: UN Publications, 2003.

34. Delgrande M, Kuntsche EN, Schmid H. Befragung zum Gesundheitsverhalten von 12- bis 15-jährigen SchülerInnen: deskriptive Statistik der 1998 erhobenen Gesamtschweizer Daten [An inquiry into the health behaviour of 12-15 year old students: descriptive statistics for Switzerland]. Lausanne: Schweizerische Fachstelle für Alkohol- und andere Drogenprobleme; 1999.

35. King A, Wold B, Smith CT, Harel Y. The health of youth: a cross-national survey.

European Series no. 69. World Health Organization Regional Publications; 1996.

http://www.euro.who.int/eprise/main/WHO/InformationSources/Publications/Catalogue/ 20040130_6 [accessed 22 December 2005].

36. McCullagh P, Nelder J. Generalized linear models, 2nd edn. London: Chapman and Hill; 1989.

37. Bryk A, Raudenbush SW. Hierarchical linear models for socialand behavioral research: applications and data analysis methods. Newbury Park, CA: Sage; 1992.

38. Hox JJ. Applied multilevel analysis, 2nd edn. Amsterdam: TTPublikaties; 1995.

39. Snijders T. Analysis of longitudanal data using the hierarchical linear model. Quality and Quantity 1996;30: 405-26.

40. Rehm J, Gmel G. Gaps and needs in international alcohol epidemiology. J Subst Use 2000;5: 6-13. 
41. Hox JJ. Multilevel modeling: when and why? In: Balderjahn I, Mathar R, Schader M, eds. Classification, data analysis, and data highways. Berlin: Springer Verlag; 1998, pp. 147-54. 42. Raudenbush SW. Hierarchical models. In: Kotz S, editor. Encyclopaedia of statistical sciences, update, vol. 3. New York: John Wiley; 1999, pp. 318-23.

43. Ter Bogt T, Fotiou A, Nic Gabhainn S. Cannabis use. In: Currie C et al., editors. Young people's health in context: health behaviour in school-aged children (HBSC) study: international report from the 2001/2002 survey. Copenhagen: World Health Organization, Regional Office for Europe; 2004, pp.84-9.

44. Abbet J-P, Rehm J, Spinatsch M. Missing values in responses to questions on drug use: the case of classroom questionnaire surveys in Swiss public schools. Addict Res 1994;1: 367-76. 45. Baron RM, Kenny DA. The mediator-moderator variable distinction in social psychological research: conceptual, strategic, and statistical considerations. J Pers Social Psychol 1986;51: 1173-82. 